\title{
Analysis of the Russian Governance
}

\author{
Valeriy Smirnov, Denis Osipov*, Vasiliy Ashmarin, Vladimir Gurdzhiyan, and Olga \\ Ezhova \\ Chuvash state University named after I.N. Ulyanov, 428015 Cheboksary, Russia
}

\begin{abstract}
The article highlights the issue of the modern Russian economy management and the theoretic representations of the general criteria of management. The research contains an analysis of the Russian management figures dynamics for the six broad aspects of management of Worldwide Governance Indicators (World Bank Group). As a result of cluster analysis of the Russian management figures growth rate there have been revealed big and important clusters. The major directions and means of management are as follows: corruption combating - corruption control; government control efficiency - rule of law and regulatory quality; political stability and absence of violence - vote and accountability. In the Russian reality there exists rationality of state government based on the rule of law, regulatory quality, freedom of speech and responsibility for the expression of will. Corruption control is manifested through the visibility of fighting it. As a result of neural network analysis of the importance of growth rates of the Russian management indicators there has been detected an hierarchy of priorities among which the Government efficiency is the most important and the least important are the reign of law, political stability and absence of violence / terrorism.
\end{abstract}

\section{Introduction}

The relevance of the Russian management figures analysis is based on the change of the global economy sustainable development conditions, transformation of the globalizing world order and, as a result, review of the principles of economic growth of the Russian economy. The issue of management is unite and diverse for the Russian economy. It is only possible to assess its scale based on the dynamics of the Russian management indicators.

Within the theoretical aspect a management shall be considered as an element, a function of organized systems of various nature (biological, social, technical) ensuring safety of their particular structure, maintaining the mode of activity, implementation of a program, achievement of the goals of activity. Labor, materials and spiritual production, distribution and consumption are impossible without particular organization, order, division of labor, determination of a place and function of a human in a team done by management. Limits of management, its content, goals and principles depend on the economic relations prevailing in the society and on the essence of the social and political system. In a bourgeois society the management is based on private capitalist property and the main

\footnotetext{
*Corresponding author: denps@mail.ru
} 
objective of bourgeoisie that, rules the society by means of government and other institutions, to strengthen its rule.

Scientific presentation of the general criteria of a state management in practical activity is related to the nature of public administration that is based on institutions. An objective and information plays a special role within this context. An objective acts as an information vector of development and information acts as a whole of behaviorally significant and defining messages $[1,2]$.

Marisella Rodriguez, Brandon J Kinne has found that to a significant extent the freedom of press and the reign of law dramatically reduce the number of offenses [3]. I.V. Zhuravleva, S.V. Zhuravlev believes that the nature of a presented image of the leader of a country (state) plays a significant role, so as his/her interaction with various persons, political activity and peculiarity of manifestations [4].

Christoph Emanuel Mueller points to the significant impact of the laws on freedom of information on improvement of the public capabilities to access the official information from government authorities [5]. Brian R. Urlacher demonstrated the possibilities to assess this impact through casual modeling [6].

Francisco Aquiles de Oliveira Caetano, Jair Andrade de Araújo, Ahmad Saeed Khan distinguished the following as defining criteria of public administration - GDP and global figures of institutional management. Using the casual modeling we can identify the positive management practices, particularly any person, group of persons or a legal entity that has an interest in resources or results of activity of public sector that would be affected by institutional management [7]. The attention is also paid to financial and economic issues of institutional management. Lucia Mihóková, Radovan Dráb, Andrea Kralik distinguish a role of taxes as a stabilizer of development of countries [8]. According to Alexey Baranov, Egor Malkov, Leonid Polishchuk, Michael Rochlitz, Georgiy Syunyaev the results of economic development are related to institutes, i.e. the "rules of the game" in economy and society that maintain particular conditions for economic activity. Effective institutes support entrepreneurship, attract investments and aid economic growth [9].

So, in general, a scientific idea of the general criteria of a country (state) governance is related to institutes and the current practical activity of public administration lies in the plane of thinking that defines institutes as the "rules of the game" within a society that defines the structure of human interaction in politics, social sphere or economy.

\section{Methods}

For the purpose of the Russian management figures analysis we use the methods of statistical, neural and cluster analysis including processing of statistical figures, their systematizing and representation in the form of diagrams and tables. Processing of statistical data is done using the IBM SPSS Statistics Software and the tables and diagrams are generated in MS Excel. Application of cluster analysis is determined by complementation of the probability understanding of casuality with the relatedness of changes of the assessed figures. Cluster analysis allows to collect data that contain information about the sampling of objects and to organize the objects of research into comparatively homogenous groups. This allows to develop qualification of studied objects or phenomena, to determine the main patterns of their grouping and to formulate hypotheses [10].

Neural network analysis allows to determine the laws of changes of objects or the phenomena by building neural networks. Hypotheses formulated using the cluster and the neural network method would allow to determine the forecast results of the applied management decisions. 
The data of the World Bank Group (WBG) defined in relation to the Worldwide Governance Indicators (WGI) became the basis for analysis of the Russian management figures. The reason for choosing the WGI is the WGB approach to management as to an aggregate of traditions and institutions that a power in a country is exercised through. It includes the process of selection, control and replacement of government; the government's ability to define and implement a policy in an effective way; respect of citizens and government to institutions that regulate economic and social interaction between them.

WGI report includes over 215 countries with six broad aspects of management described: (1) vote and accountability; (2) political stability and absence of violence; (3) effective governance; (4) quality of regulation; (5) rule of the law; (6) corruption combating.

\section{Results and discussion}

As a result of the Russian management figures growth rates cluster analysis the following complex clusters (Table 1) are identified: (1) large - a basis is corruption combating; (2) important - a basis is: (a) public administration efficiency and (b) political stability and absence of violence.

Table 1. Clusters of the Russian management figures growth rates, 1998 - 2018

\begin{tabular}{|c|c|c|}
\hline \multicolumn{2}{|r|}{ Cluster } & \multirow{2}{*}{\begin{tabular}{|c|c}
$\begin{array}{c}\text { Square of } \\
\text { the } \\
\text { Euclidean } \\
\text { distance }\end{array}$ \\
$2.2 \mathrm{E}+03$ \\
\end{tabular}} \\
\hline \multirow{13}{*}{$\begin{array}{l}\text { Corruption combating: } \\
\text { assessment }\end{array}$} & Corruption control: standard error & \\
\hline & Corruption combating: number of sources & $3.7 \mathrm{E}+03$ \\
\hline & Government efficiency: percentile rank & $6.3 \mathrm{E}+03$ \\
\hline & Corruption control: percentile rank & $6.9 \mathrm{E}+03$ \\
\hline & Vote and accountability: assessment & $1.3 \mathrm{E}+04$ \\
\hline & $\begin{array}{l}\text { Political stability and absence of violence / } \\
\text { terrorism: assessment }\end{array}$ & $1.7 \mathrm{E}+04$ \\
\hline & $\begin{array}{l}\text { Government efficiency: percentile rank, lower } \\
\text { limit of } 90 \% \text { confidence interval }\end{array}$ & $2.2 \mathrm{E}+04$ \\
\hline & $\begin{array}{l}\text { Political stability and absence of violence / } \\
\text { terrorism: percentile rank }\end{array}$ & $3.0 \mathrm{E}+04$ \\
\hline & Government efficiency: assessment & $3.6 \mathrm{E}+04$ \\
\hline & $\begin{array}{l}\text { Corruption control: percentile rank, lower limit } \\
\text { of } 90 \% \text { confidence interval }\end{array}$ & $4.6 \mathrm{E}+04$ \\
\hline & Regulatory quality: assessment & $6.4 \mathrm{E}+04$ \\
\hline & $\begin{array}{l}\text { Political stability and absence of violence / } \\
\text { terrorism: percentile rank, lower limit of } 90 \% \\
\text { confidence interval }\end{array}$ & $1.6 \mathrm{E}+05$ \\
\hline & Vote and accountability: percentile rank & $2.0 \mathrm{E}+03$ \\
\hline \multirow{2}{*}{$\begin{array}{l}\text { Public administration } \\
\text { efficiency: number of } \\
\text { sources }\end{array}$} & Rule of the law: number of sources & $2.6 \mathrm{E}+02$ \\
\hline & Regulatory quality: number of sources & $4.5 \mathrm{E}+02$ \\
\hline \multirow{2}{*}{$\begin{array}{l}\text { Political stability and } \\
\text { absence of violence / } \\
\text { terrorism: standard error }\end{array}$} & Vote and accountability: standard error & $7.9 \mathrm{E}+02$ \\
\hline & Rule of the law: standard error & $1.1 \mathrm{E}+03$ \\
\hline $\begin{array}{l}\text { Political stability and } \\
\text { absence of violence / } \\
\text { terrorism: number of sources }\end{array}$ & Vote and accountability: number of sources & $7.4 \mathrm{E}+02$ \\
\hline
\end{tabular}

Note: Hierarchical cluster analysis - the average distance between clusters, the square of the Euclidean distance. 
Source: calculated in "IBM SPSS Statistics Software" according to the World Bank Group, All Rights Reserved. Data Catalog. Worldwide Governance Indicators. https://datacatalog.worldbank.org (Access: 2020/11/19).

Major directions and means of management: corruption combating - corruption control; public administration efficiency - rule of the law and regulatory quality;

- political stability and absence of violence - vote and accountability.

So, the result of cluster analysis is a provision on presence in the Russian reality of reasonability of governance based on the rule of the law, regulatory quality, freedom of speech and responsibility for the expression of will. At the same time the corruption control is manifested through visibility of combating it.

As a result of neural network analysis of the importance of growth rates of the Russian management indicators there has been detected a hierarchy of priorities (Table 2) among with the Government efficiency as the most important and the reign of law, political stability and absence of violence / terrorism as the least important.

Table 2. Neural network analysis of importance of the Russian management figures growth rates, 1998-2018

\begin{tabular}{|c|c|}
\hline Indicator & Importance $\mathbf{> 5 0 \%}$ \\
\hline $\begin{array}{c}\text { Government efficiency: percentile rank, upper limit of the 90\% } \\
\text { confidence interval }\end{array}$ & 100.0 \\
\hline $\begin{array}{c}\text { Government efficiency: standard error } \\
\text { Regulatory quality: percentile rank } \\
\begin{array}{c}\text { Regulatory quality: percentile rank, upper limit of 90\% confidence } \\
\text { interval }\end{array}\end{array}$ & 70.0 \\
\hline $\begin{array}{c}\text { Political stability and absence of violence / terrorism: percentile rank, } \\
\text { upper limit of 90\% confidence interval }\end{array}$ & 73.5 \\
\hline $\begin{array}{c}\text { Government efficiency: percentile rank, lower limit of 90\% confidence } \\
\text { interval }\end{array}$ & 69.7 \\
\hline $\begin{array}{c}\text { Regulatory quality: number of sources } \\
\text { Corruption combating: assessment }\end{array}$ & 69.0 \\
\hline Government efficiency: assessment & 63.8 \\
\hline Rule of the law: assessment & 60.8 \\
\hline Regulatory quality: assessment & 60.4 \\
\hline Public administration efficiency: number of sources & 59.8 \\
\hline
\end{tabular}

Note. Multilayer perception, batch training.

Source: calculated in "IBM SPSS Statistics Software" according to the World Bank Group, All Rights Reserved. Data Catalog. Worldwide Governance Indicators. https://datacatalog.worldbank.org (Access: 2020/11/19).

The aggregate of cluster and neural network analysis results allows to identify the controversies in relation to political stability and absence of violence / terrorism that is manifested in the capability to ignore the rule of the law, regulatory quality, vote and accountability to achieve efficiency of public administration.

As a result of assessment of asymmetry of the Russian management figures dynamics distribution in relation to an average value there is identified the priority - Government efficiency.

Thus the results of cluster and neural network analysis, assessment of asymmetry of the Russian management figures distribution dynamics in relation to the average value allow to suggest that the Government efficiency is the determining criteria of management. Government efficiency is manifested in maintaining political stability and absence of violence / terrorism by means including ignoring of the rule of the law, regulatory quality, vote and accountability and be creating an image that corruption combating takes place.

Russia has various options to raise the level of governance. For example, Yashar Tarverdi, Shrabani Saha, Neil Campbell claims that the level of democracy affects the 
quality of governance. In the countries with dictatorship, as a rule, the level of governance is higher than in the countries with partially democratized economy (electoral democracies) [11].

Vicki Hesli Claypool, William M. Reisinger, Marina Zaloznaya, Yue Hu, Jenny Juehring believe that the only representative of state that people deal with is the corrupted political leaders not deserving electoral support [12].

Chien-Chiang Lee, Shan-Ju Ho, Chih-Wei Wang claims that corruption has adverse effect on the probability of innovations. Political subtext consists in that the Government shall strengthen the positive role (Government efficiency) - the rule of the law, regulatory qualities and corruption control in order to improve innovations of companies [13].

In general the efficiency of government activity for maintaining political stability and absence of violence / terrorism by means of is quite achievable in the framework of the existing political structure of Russia.

\section{Conclusions}

Opportunities for sustainable growth of the Russian economy in the localizing world are significantly limited by the existing socio-economic formation and the dominating standards of political structure of Russia.

At the same time these limitations allow to highlight efficiency of Government activity as the determining criterion of governance. In this event the Government efficiency is manifested in maintaining political stability and absence of violence / terrorism by means including ignoring of the rule of the law, regulatory quality, vote and accountability and be creating an image that corruption combating takes place.

\section{References}

1. V. V. Smirnov, D.G. Osipov, A.A. Babaeva, E.V. Grigorieva, E.F. Perfilova, 1st International Scientific Conference "Modern Management Trends and the Digital Economy: from Regional Development to Global Economic Growth" (MTDE 2019). Advances in Economics, Business and Management Research, 81, 22 (2019)

2. V. V. Smirnov, D. G. Osipov, A. A. Babaeva. 2020 IOP Conf. Ser.: Mater. Sci. Eng. 753 052062, IOP Conference Series: Materials Science and Engineering, 753(5) (2020)

3. M. Rodriguez, B. J. Kinne, International Studies Quarterly, 63(3), 626 (2019)

4. I. V. Zhuravleva, S. V. Zhuravlev, Procedia - Social and Behavioral Sciences, 166, 541 (2015)

5. C. E. Mueller, International Journal of Public Administration, 42(12), 1020 (2019)

6. B. R. Urlacher, American Behavioral Scientist, 64(1), 55 (2019)

7. F. Aquiles de Oliveira Caetano, J. Andrade de Araújo, A. S. Khan, Interações (Campo Grande), 20(1) (2019)

8. L. Mihóková, R. Dráb, A. Kralik, Acta Univ. Agric. Silvic. Mendelianae Brun, 67, 515 (2019)

9. A. Baranov, E. Malkov, L. Polishchuk, M. Rochlitz, G. Syunyaev, Russian Journal of Economics, 1(2), 154 (2015)

10. A. Adolfsson, M. Ackerman, N. C. Brownstein, Pattern Recognition, 88, 13 (2019)

11. Y. Tarverdi, S. Saha, N. Campbell, Economic Analysis and Policy, 63, 220 (2019)

12. V.H. Claypool, W.M. Reisinger, M. Zaloznaya, Y. Hu, J. Juehring, Electoral Studies, 54, $182(2018)$ 
13. C.-C. Lee, C.-W. Wang, S.-J. Ho, Economic Modelling, 92, 326 (2020) 